\title{
DETAILS AND SIGNIFICANCE OF PRE-KETILIDIAN DOLERITE DYKES IN AN AREA NORTH-EAST OF BJØRNESUND, NEAR FISKENÆSSET, WEST GREENLAND
}

\author{
H. R. Williams
}

\section{Introduction}

Three sets of dolerite dykes cut all pre-Ketilidian structures in an area north-east of Bjørnesund, where they are intimately associated with transcurrent faults. The earliest dykes trend approximately north-south, are followed by an east-north-east trending set, which in turn are cut by the youngest and most abundant set, trending east-south-east. The east-north-east set may be subdivided into subordinate north-east, and dominant east-north-east trending swarms. Similar field relations have been recorded by Chadwick (1969), Dawes (1970), Jensen (1966), Rivalenti \& Sighinolfi (1971), and by many others in unpublished GGU reports. Recent mineralogical and geochemical work by Rivalenti \& Sighinolfi concerns similar dykes in the Frederikshåb area to the south. Within the area south and east of Fiskenæsset, the field relations and petrological characteristics of the dykes are relatively uniform, according to information furnished by colleagues working in adjacent areas.

\section{Field occurrence}

Field data are presented in Table 16. All dykes exhibit chilled margins, some contain internal chills and other multiple intrusion phenomena. The earlier two sets are not numerous, rendering an analysis of their trends and occurrence unreliable. The youngest, east-south-east swarm, contains twenty dykes. Most are concentrated in areas dominated by structures parallelling their trend, produced in the preceding, pre-Ketelidian, tectonothermal event. All dykes are vertical and straight except where they cross-cut faults. Some faults appear to have locally reoriented the regional stress pattern, such that a dyke may assume a different trend, and sometimes occupies the fault for some distance.

\section{Internal textural phenomena}

The east-south-east and east-north-east dolerites both contain structures indicating the process of multiple intrusion. The most common of these is the presence of internal chills. Movement of magma from the central, unconsolidated portion of a dyke often occurs, breaking through the initial chilled zone into the surrounding host rock. Perhaps the most striking feature is the vertical banding present in many of the east-south-east dykes with widths of more than $5 \mathrm{~m}$. Bands of feldspathic and normal dolerite are longitudinally impersistent, and can only be traced for $30 \mathrm{~m}$. Bands are normally restricted to the doleritic portions of each intrusion, the gabbroic central parts are homogeneous. A process involving either multiple injection of magma, or variation in physical conditions, such 
Table 16. Field and petrological data for Bjørnesund dolerites

\begin{tabular}{|c|c|c|c|}
\hline Dyke set & North-south & East-north-east & East-south-east \\
\hline Width & 0.8 to $25 \mathrm{~m}$ & Up to $50 \mathrm{~m}$ & Up to $50 \mathrm{~m}$ \\
\hline $\begin{array}{l}\text { Fault } \\
\text { association }\end{array}$ & close to or within fau & lts of similar trend & $\begin{array}{l}\text { Parallel with, but } \\
\text { not associated with } \\
\text { ESE faults }\end{array}$ \\
\hline $\begin{array}{l}\text { Chilled } \\
\text { margins }\end{array}$ & Always & $\begin{array}{l}\text { present, large dykes have } \\
\text { centres, rare pegmatites }\end{array}$ & gabbroic \\
\hline Trend & 150 to 180 , vertical & $\begin{array}{l}065 \text { to } 090 \text {, vertical } \\
038 \text { to } 045 \text {, vertical }\end{array}$ & $\begin{array}{l}090 \text { to } 140 \text {, vertical } \\
\text { mean trend } 120\end{array}$ \\
\hline $\begin{array}{l}\text { Number of } \\
\text { dykes }\end{array}$ & 6 & 8 & 20 \\
\hline $\begin{array}{l}\text { Characteri- } \\
\text { stics }\end{array}$ & $\begin{array}{l}\text { Generally thin, but } \\
\text { very persistent. Large } \\
\text { dykes contain many } \\
\text { poikocrysts }\end{array}$ & $\begin{array}{l}\text { Some evidence of mul- } \\
\text { tiple intrusion. } \\
\text { Margins often fault } \\
\text { bounded, epidosites }\end{array}$ & $\begin{array}{l}\text { Commonly show en } \\
\text { echelon and en } \\
\text { bayonet structures. } \\
\text { Large dykes induce } \\
\text { melting of contact } \\
\text { rocks }\end{array}$ \\
\hline Olivine & $\begin{array}{l}\text { Euhedral \& skeletal } \\
\text { phenocrysts, poiko- } \\
\text { crysts, interstitial } \\
\text { grains }\end{array}$ & $\begin{array}{l}\text { Phenocrysts in large } \\
\text { dykes only }\end{array}$ & $\begin{array}{l}\text { Very rare phenocrysts } \\
\text { completely altered }\end{array}$ \\
\hline Hypers thene & $\begin{array}{l}\text { Phenocrysts and } \\
\text { interstitial grains }\end{array}$ & $\begin{array}{l}\text { Phenocrysts in large } \\
\text { dykes only }\end{array}$ & Not present \\
\hline Augite & $\begin{array}{l}\text { Phenocrysts and } \\
\text { mantles around hyper- } \\
\text { sthene, interstitial }\end{array}$ & $\begin{array}{l}\text { Phenocrysts, glomero- } \\
\text { porphyritic and } \\
\text { interstitial grains }\end{array}$ & $\begin{array}{l}\text { Zoned glomeroporphy- } \\
\text { ritic and interstiti- } \\
\text { al grains }\end{array}$ \\
\hline Plagioclase & $\begin{array}{l}\text { Resorbed phenocrysts, } \\
\text { zoned poikocrysts, } \\
\text { variolitic and normal } \\
\text { laths, An } 45-65\end{array}$ & $\begin{array}{l}\text { Zoned poikocrysts, } \\
\text { phenocrysts and } \\
\text { laths, An } 45-65\end{array}$ & $\begin{array}{l}\text { Zoned, resorbed } \\
\text { phenocrysts and } \\
\text { laths, An } 45-55\end{array}$ \\
\hline $\begin{array}{l}\text { Magnetite } \\
\text { Ilmenite }\end{array}$ & Interstitial grains & Interstitial grains & $\begin{array}{l}\text { Interstitial grains. } \\
\text { Large, altered, sub- } \\
\text { hedral plates }\end{array}$ \\
\hline Alteration & $\begin{array}{l}\text { Plagioclase stained } \\
\text { brown, chlorite and } \\
\text { white mica }\end{array}$ & $\begin{array}{l}\text { Small dykes often } \\
\text { wholly altered to } \\
\text { chlorite and white } \\
\text { mica, epidosites }\end{array}$ & $\begin{array}{l}\text { Uralitic hornblende, } \\
\text { biotite and chlorite } \\
\text { leucozene from ilme- } \\
\text { nite }\end{array}$ \\
\hline
\end{tabular}


as water vapour pressure, during precipitation of the silicate phases from the magma, is considered to be the most likely cause of these banded rocks (Williams, 1973).

\section{Petrography}

Brief mineralogical data are presented in Table 16. Most of the dykes are mediumgrained, sometimes porphyritic dolerites, the larger ones containing gabbroic centres. The older two sets contain phenocrysts of all the normal silicate phases found in dolerites, while the east-south-east set contains only zoned plagioclase phenocrysts and glomeroporphyritic clots of clinopyroxene. Plagioclase phenocrysts show frequent signs of partial resorption, while the olivine and orthopyroxene phenocrysts are often mantled by clinopyroxene.

Up to $5 \%$ interstitial alkali feldspar - quartz intergrowth is found in the latest set of dykes, being absent in the first two.

Dykes associated with, or sampled near to faults are frequently altered. East-southeast dykes are more altered than others, perhaps due to mild autometamorphism. They contain abundant uralitic hornblende developed from clinopyroxene, minor biotite, chlorite, leucoxene plates and white mica. A more hydrous assemblage is characteristic of these east-south-east dolerites.

\section{Chemistry}

The AFM diagram (fig. 43) indicates that most of the dolerites have compositions that plot along an iron-enrichment trend. No significant variation in major-element chemistry can be recognised with respect to dyke size or trend, excepting some dykes in the northsouth swarm. Of the six dykes analysed from this set, three are poor in iron and titanium, but rich in magnesium. These magnesian rocks are extremely coarse-grained, rich in euhedral phenocrysts and poikocrysts of olivine and hypersthene, and poor in magnetite. They may represent a relatively primitive magma, a differentiated portion of which was responsible for the remaining intrusions.

Average $\mathrm{K}_{2} \mathrm{O}$ wt.\% composition for the three swarms taken together is 0.6 , a value found in many continental tholeiites and dolerites.

Fig. 43. AFM diagram plotted as weight per cent oxides of dolerites from southern West Greenland.

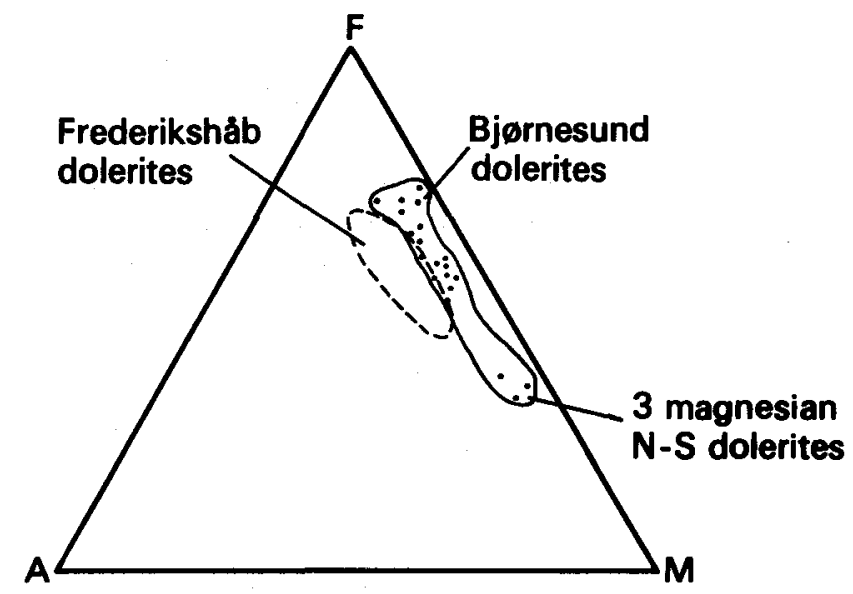


Table 17. Correlation of dyke trends

\begin{tabular}{lcccc}
\hline Bjornesund & Frederikshá* & $\begin{array}{c}\text { Godthå } \\
\text { Sukkertoppen }\end{array}$ & $\begin{array}{c}\text { Canadiant } \\
\text { Shield }\end{array}$ & $\begin{array}{c}\text { North-west } \\
\text { Scotland }\end{array}$ \\
\hline N-S & $M_{1}(160)$ & 010,160 & & \\
ENE & $M_{2}(040-060)$ & $065-105$ & Yellowknife & Scourie dyke \\
ESE & $M_{3}(090-120)$ & 130 & \& Ungava & swarm \\
\hline * from Berthelsen \& Bridgwater (1960), Jensen (1962) & \\
* from Jensen (1966) & & & \\
+ from Payne et al. (1965), Bridgwater et al. (1973) &
\end{tabular}

Figure 43 also shows the position of the dolerites analysed by Rivalenti \& Sighinolfi, from the Frederikshåb area. The variation in composition of the Bjørnesund dolerites is slightly greater than that in the Frederikshåb rocks; total alkalies are significantly different but the variation may be analytical in origin. The average compositions of the two groups are very similar. Comparison with other analysed continental basaltic rocks suggests that there are few significant major-element differences between many of these and the preKetilidian dolerites of West Greenland.

\section{Correlations and their significance}

Although incomplete, mapping has provided the data upon which the following correlations have been made (Table 17).

In West Greenland there is a close correlation between dyke trend and relative age. Mineralogical data support these field correlations.

The Canadian and Scottish dyke swarms of late Archaean age have been correlated with those in West Greenland by Payne et al. (1965), and Bridgwater et al. (1973). After allowance/is made for the effects of continental break-up and drift, the Archaean dykes describe a great circle across the North Atlantic Craton. The dykes were intruded at the end of a long period of thermal and tectonic activity, at a time when the crust was first able to fracture on a large scale. Previously, dyke swarms were of a relatively local extent, reflecting the distribution and size of crustal material competent enough to support fractures. The dyke intrusion event is a world-wide one, examples of late Archaean dolerites occur also in Australia (McCall \& Peers, 1971) and Rhodesia (Wilson, 1973), suggesting that a global change in crustal conditions was responsible for the cooling and fracturing of the continental crust. 


\section{References}

Berthelsen, A. \& Bridgwater, D. 1960: On the field occurrence and petrography of some basic dykes of supposed pre-Cambrian age from the southern Sukkertoppen District, western Greenland. Bull. Grønlands geol. Unders. 24 (also Meddr Grønland 123,3) 43 pp.

Bridgwater, D., Watson, J. \& Windley, B. F. 1973: The Archaean craton of the North Atlantic region. Phil. Trans. R. Soc. Lond. A, 273, 493-512.

Chadwick, B. C. 1969: Patterns of fracture and dyke intrusion near Frederikshåb, southwest Greenland. Tectonophysics 8, 247-264.

Dawes, P. R. 1970: Bedrock geology of the nunataks and semi-nunataks in the Frederikshåbs Isblink area of southern west Greenland. Rapp. Grønlands geol. Unders. 29, 60 pp.

Jensen, S. B. 1962: Some dolerite dykes in the southern part of the Godthaab District, West Greenland, Meddr Grønland 169,4, 38 pp.

Jensen, S. B. 1966: Fieldwork in the Frederikshåb area. Rapp. Grønlands geol. Unders. 11, 32-35.

McCall, G. J. H. \& Peers, R. 1971: Geology of the Binneringie Dyke. Geol. Rdsch. 60, 1174-1263.

Payne, A. V., Baadsgaard, H., Burwash, R. A., Cumming, G. L., Evans, C. R. \& Folinsbee, R. E. 1965: A line of evidence supporting continental drift. Int. Union geol. Sci. Upper Mantle Symposium. New Delhi, 1964, 83-93. Copenhagen: Berlingske.

Rivalenti, G. \& Sighinolfi, G. P. 1971: Geochemistry and differentiation phenomena in basic dikes of the Frederikshåb District, South West Greenland. Atti. Soc. tosc. Sci. Nat. Mem. A. 77, 358-380.

Williâms, H. R. 1973: The geology of an area to the northeast of Bjørnesund, near Fiskenæsset, west Greenland. Unpubl. Ph. D. thesis, Univ. Exeter.

Wilson, J. F. 1973: The Rhodesian Archaean Craton. Phil. Trans. R. Soc. Lond. A, 273, 389-411. 